\title{
ARTYKUŁY
}

Klio. Czasopismo poświęcone dziejom Polski i powszechnym

PL ISSN 1643-8191, t. 26 (3)/2013, s. 55-80

(c) (1) $\Theta$

DOI: http://dx.doi.org/10.12775/KLIO.2013.033

\section{Matgorzata MachateK}

(Szczecin)

\section{Przemiany polskiej wsi w latach 1918-1989}

\begin{abstract}
Choć aż do drugiej połowy XX w. większość polskiego społeczeństwa stanowiła ludność wiejska, to jednak historia wsi stosunkowo rzadko zajmuje uwagę badaczy. Wprawdzie dotychczas ukazało się sporo opracowań szczegółowych, to jednak wciąż widoczny jest deficyt publikacji o charakterze syntetycznym i podręcznikowym, zwłaszcza poświęconych historii gospodarczej oraz dziejom wsi w XX w. Szczególnie rzadko tematyka wiejska znajduje odzwierciedlenie w materiałach dydaktycznych ${ }^{1}$. Celem niniejszego artykułu, opartego w głównej mierze na dotychczasowej literaturze, jest zatem przybliżenie tej marginalizowanej dotąd tematyki i zachęcenie do podejmowania jej również w edukacji historycznej.

W dziejach polskiej wsi w XX w. zdecydowanie więcej było okresów niekorzystnych niż okresów dobrej koniunktury gospodarczej i politycznej. W latach międzywojennych nie udało się rozwiązać najważniejszych pro-
\end{abstract}

${ }^{1} \mathrm{~J}$. Styk, Aktualne kierunki badań nad historia polskiej wsi do 1939 roku. Rekonesans bibliograficzny, [w:] Wieś jako przedmiot badań naukowych na poczatku XXI wieku, red. M. Halamska, Warszawa 2011, s. 209-220; A. W. Kaczorowski, Wieś w publikacjach Instytutu Pamięci Narodowej, [w:] tamże, s. 221-224 
blemów związanych ze strukturą agrarną i przeludnieniem. Wojna i okupacja pogłębiły biedę oraz zacofanie gospodarcze wsi, a po drugiej wojnie światowej błędna polityka państwa zaowocowała nie tylko stagnacją gospodarczą w rolnictwie, ale również pogorszeniem poziomu życia wszystkich mieszkańców kraju. Jednocześnie rolnicy ponosili większość ciężarów związanych z industrializacją gospodarki, a dystans dzielący polskie rolnictwo od zachodniego systematycznie się zwiększał. Znacznie wolnej niż na zachodzie Europy przebiegały też procesy modernizacyjne, co miało negatywny wpływ na poziom życia na wsi.

\section{Lata 1918-1939}

\section{Liczba i zróżnicowanie ludności wiejskiej}

W okresie międzywojennym ludność wiejska stanowiła aż 73\% ogółu mieszkańców kraju (dane ze spisu z 1931 r.) ${ }^{2}$. Wśród mieszkańców wsi dominującą, choć wewnętrznie zróżnicowaną grupą byli chłopi (tab. 1). Rolnictwo stanowiło też źródło utrzymania dla ziemian oraz robotników rolnych zatrudnionych $\mathrm{w}$ folwarkach należących do wielkich właścicieli ziemskich. Tylko nieliczni mieszkańcy wsi wykonywali zawody pozarolnicze (np. nauczyciele, urzędnicy, rzemieślnicy).

Tabela 1. Szacunek liczebności i podziału „klasowo-warstwowego” ludności chłopskiej (w mln)

\begin{tabular}{|l|c|c|c|}
\hline Kategorie społeczne & $\mathbf{1 9 2 1 ~ r . ~}$ & $\mathbf{1 9 3 1} \mathbf{~ r .}$ & $\mathbf{1 9 3 8} \mathbf{~ r .}$ \\
\hline $\begin{array}{l}\text { Ludność Polski } \\
\text { ogółem }\end{array}$ & 27,2 & 32,1 & 34,1 \\
\hline Chłopi ogółem & 14,2 & 16,4 & 17,4 \\
\hline Półproletariat & 1,2 & 1,6 & 1,8 \\
\hline Małorolni & 5,9 & 6,8 & 7,3 \\
\hline
\end{tabular}

${ }^{2}$ Liczba ludności rolniczej w okresie międzywojennym zwiększyła się o 18,5\%. M. Mieszczankowski, Struktura agrarna Polski międzywojennej, Warszawa 1960, s. 310. 
Cd. tab. 1

\begin{tabular}{|l|c|c|c|}
\hline Kategorie społeczne & $\mathbf{1 9 2 1} \mathbf{~ r .}$ & $\mathbf{1 9 3 1} \mathbf{r .}$ & $\mathbf{1 9 3 8} \mathbf{~ r .}$ \\
\hline Średniorolni & 5,3 & 6,2 & 6,4 \\
\hline Grupa „kmieca” & 1,8 & 1,8 & 1,9 \\
w tym „wielkok- & 0,3 & 0,3 & 0,3 \\
mieca” & & & \\
\hline
\end{tabular}

Źródło: J. Żarnowski, Społeczeństwo II Rzeczypospolitej, Warszawa 1973, tab. 28.

Jednym z najważniejszych problemów wsi w tym okresie było ogromne przeludnienie. $\mathrm{Na} 100$ ha gruntów ornych, łąk i pastwisk przypadało w Polsce w połowie lat trzydziestych 81 osób, podczas gdy w Niemczech - 49, Czechosłowacji - 64, a w Danii tylko 36. Jednocześnie plony w tych krajach były znacznie wyższe niż w Polsce ${ }^{3}$. Skala przeludnienia była zróżnicowana regionalnie - najwyższe było ono w województwach południowych, a najniższe w Wielkopolsce, co ilustruje tabela 2.

Tabela 2. Ludność rolnicza przypadająca na 100 ha użytków rolnych

\begin{tabular}{|c|c|c|c|c|c|}
\hline \multirow{2}{*}{ Rok } & \multirow{2}{*}{ Polska } & \multicolumn{4}{|c|}{ Województwa } \\
\cline { 3 - 6 } & & centralne & wschodnie & zachodnie & południowe \\
\hline 1921 & 71,2 & 72,5 & 52,3 & 57,0 & 102,4 \\
\hline 1931 & 76,5 & 77,9 & 60,6 & 54,1 & 108,4 \\
\hline 1938 & 81,5 & 83,2 & 65,0 & 58,1 & 114,9 \\
\hline
\end{tabular}

Źródło: M. Mieszczankowski, Rolnictwo II Rzeczypospolitej, Warszawa 1983, s. 52.

Problem ten był trudny do rozwiązania, ponieważ zbyt słaby przemysł nie był w stanie wchłonąć nadwyżki rąk do pracy występującej na wsi. W tej sytuacji coraz więcej osób decydowało się na emigrację. Szacuje się,

3 Ibidem, s. 54. Według niektórych autorów przeludnienie na wsi było jeszcze wyższe i w województwach południowych sięgało nawet 300 osób, zob.: I. Ihnatowicz, A. Mączak, B. Zientara, J. Żarnowski, Spoteczeństwo polskie od X do XX wieku, Warszawa 1988, s. 623. 
że tylko w latach 1926-1928 wyjechało z kraju za chlebem około 0,5 mln mieszkańców wsi, choć rzeczywiste dane mogły być wyższe ${ }^{4}$.

\section{Struktura agrarna}

Kolejnym problemem, który wpływał na kondycję polskiego rolnictwa była niekorzystna struktura agrarna. Dominowały gospodarstwa karłowate o powierzchni poniżej 2 ha i gospodarstwa małorolne $(61,6 \%$ ogółu gospodarstw). Oznacza to, że przeszło połowa gospodarstw chłopskich była zbyt mała, aby zapewnić wystarczające środki na utrzymanie rodziny. Jednocześnie właśnie w tych najmniejszych gospodarstwach występowały największe nadwyżki siły roboczej. Natomiast wielkie gospodarstwa i majątki o powierzchni powyżej 50 ha stanowiły niespełna $1 \%$ ogółu gospodarstw, ale zajmowały ponad 48\% gruntów rolniczych (z tego 20\% ziemi należało do majątków liczących powyżej 1000 ha). Najwięcej wielkich majątków znajdowało się na Kresach Wschodnich oraz w Wielkopolsce, na Pomorzu i na Śląsku.

Tabela 3. Struktura posiadania ziemi w Polsce według spisu z 1921 r.*

\begin{tabular}{|c|c|c|c|c|}
\hline \multirow{2}{*}{$\begin{array}{c}\text { Liczba } \\
\text { gospodarstw }\end{array}$} & \multicolumn{2}{|c|}{ Liczba } & \multicolumn{2}{c|}{ Powierzchnia } \\
\cline { 2 - 5 } & $\begin{array}{c}\text { gospodarstw } \\
\text { w tysiącach }\end{array}$ & w \% ogółu & $\begin{array}{c}\text { gospodarstwa } \\
\text { w tysiącach ha }\end{array}$ & $\begin{array}{c}\text { w \% ogólnej } \\
\text { powierzchni }\end{array}$ \\
\hline Ogółem & 3490,7 & 100,0 & 37926,0 & 100,0 \\
\hline $0-2$ & 1013,4 & 29,0 & 1060,7 & 2,8 \\
\hline $2-5$ & 1138,5 & 32,6 & 4248,3 & 11,2 \\
\hline $5-0$ & 861,1 & 24,7 & 6562,6 & 17,3 \\
\hline
\end{tabular}

${ }^{4}$ M. Mieszczankowski, op. cit., s. 311.

5 Ibidem, s. 337-338; H. Słabek, Dzieje polskiej reformy rolnej 1944-1948, Warszawa 1972, s. 20-23; J. Kaliński, Z. Landau, Gospodarka Polski w XX wieku, Warszawa 2003, s. 64. 
Cd. tab. 3

\begin{tabular}{|c|c|c|c|c|}
\hline \multirow{2}{*}{$\begin{array}{c}\text { Liczba } \\
\text { gospodarstw }\end{array}$} & \multicolumn{2}{|c|}{ Liczba } & \multicolumn{2}{c|}{ Powierzchnia } \\
\cline { 2 - 5 } & $\begin{array}{c}\text { gospodarstw } \\
\text { w tysiącach }\end{array}$ & w \% ogółu & $\begin{array}{c}\text { gospodarstwa } \\
\text { w tysiącach ha }\end{array}$ & $\begin{array}{c}\text { w \% ogólnej } \\
\text { powierzchni }\end{array}$ \\
\hline $10-20$ & 360,0 & 10,3 & 5201,7 & 13,7 \\
\hline $20-50$ & 87,6 & 2,5 & 2611,1 & 6,9 \\
\hline powyżej 50 & 30,1 & 0,9 & 18241,6 & 48,1 \\
\hline
\end{tabular}

* Spis z 1921 r. nie uwzględnił ok. 16\% ogólnej powierzchni - brak województwa wileńskiego oraz Górnego Śląska. M. Mieszczankowski, op. cit., s. 18.

Źródło: Z. Landau, J. Tomaszewski, Gospodarka Drugiej Rzeczypospolitej, Warszawa 1991, s. 10 .

Dane z tabeli 3 nie pokazują jednak różnic regionalnych będących konsekwencją historycznych uwarunkowań, zwłaszcza odmienności polityki państw zaborczych wobec wsi. W województwach zachodnich dominowały duże gospodarstwa chłopskie, tylko takie bowiem mogły w XIX w. skutecznie przeciwstawić się polityce pruskiego zaborcy dążącego do przejęcia polskiej własności. Wykorzystywano w nich nowoczesne metody gospodarowania, praca była w dużej części zmechanizowana, stosowano też duże ilości nawozów sztucznych. Istniał też rynek zbytu na produkty rolne wywożone głównie w głąb Niemiec. Natomiast na ziemiach byłego zaboru rosyjskiego nastąpiło poważne rozdrobnienie gospodarstw rolnych, będące efektem częstych podziałów ziemi. $\mathrm{Na}$ wsi dominowały gospodarstwa drobnotowarowe prowadzące gospodarkę ekstensywną, a na słabym rynku zbytu istniała silna konkurencja w postaci tanich towarów przywożonych z głębi Rosji. Jeszcze większym rozdrobnieniem i przeludnieniem charakteryzowały się województwa południowe (dawna Galicja). Na efektywność gospodarowania negatywnie wpływała też tzw. szachownica gruntów. Spis z 1921 r. wykazał, że 46,8\% gospodarstw miało swoje grunty orne w kilku kawałkach ${ }^{6}$. Konieczna zatem była ich komasacja, jednak do końca okre-

${ }^{6} \mathrm{Z}$ tego $27 \%$ gospodarstw miało grunty w przynajmniej czterech częściach. W skrajnych przypadkach tych „kawałków” było nawet kilkaset. Zdarzało się również, że grunty należące do jednego gospodarstwa znajdowały się nie tylko na terenie danej wsi, ale 
su międzywojennego zdołano scalić jedynie $60 \%$ rozdrobnionych gruntów w województwach centralnych i południowych ${ }^{7}$.

\section{Reformy rolne w II RP}

Większość ugrupowań politycznych dostrzegała konieczność zmiany niekorzystnej struktury agrarnej wsi, dlatego już w 1919 r. sejm przyjął uchwałę o parcelacji majątków państwowych i wykupie nadwyżek ziemi w majątkach prywatnych. Maksymalną powierzchnię gospodarstw ustalono na 180 ha, a w województwach wschodnich i zachodnich - na 400 ha. Z powodu sporów politycznych uchwała nie weszła jednak w życie. Bardziej radykalny wariant reformy został przyjęty przez sejm w lipcu 1920 r. w obliczu dramatycznej sytuacji spowodowanej wojną polsko-bolszewicką. Uchwalona wówczas ustawa o wykonaniu reformy rolnej przewidywała przymusowy wykup nadwyżek ziemi w majątkach prywatnych (powyżej 60 ha w okręgach przemysłowych, powyżej 400 ha na obszarze byłego zaboru pruskiego i na ziemiach wschodnich oraz 180 ha na pozostałym obszarze państwa)8. Wywłaszczani właściciele mieli otrzymać odszkodowania na poziomie 50\% przeciętnej wartości rynkowej ziemi. Decyzja ta wywołała liczne protesty środowisk ziemiańskich i endecji.

Po wejściu w życie konstytucji marcowej z 1921 r., wprowadzającej zasadę nienaruszalności własności prywatnej, realizacja reformy napotkała poważne przeszkody. W praktyce parcelację ograniczono więc głównie do majątków państwowych. Sprawa reformy rolnej została ponownie podjęta w 1925 r. Przyjęta wówczas ustawa zakładała coroczną parcelację 200 tys. ha (przez 10 lat). Górną granicę powierzchni gospodarstw ustalono na

również sąsiednich. Największe rozdrobnienie występowało na Podlasiu, zob.: I. BukrabaRylska, Socjologia wsi polskiej, Warszawa 2008, s. 196-197.

7 J. Skodlarski, Zarys historii gospodarczej Polski, Warszawa 2007, s. 250; J. Kaliński, Z. Landau, op. cit., s. 146. Najbardziej opornie przebiegała komasacja na obszarze byłej Galicji, gdzie panowało ogromne przywiązanie do tradycyjnego układu pól. Na terenie województw zachodnich komasacja w zasadzie nie była potrzebna - scalono zaledwie kilka wsi, zob.: I. Bukraba-Rylska, op. cit., s. 197.

${ }^{8}$ J. Skodlarski, op. cit., s. 250. 
60-180 ha w Polsce centralnej oraz 300 ha na obszarze województw wschodnich i 700 ha dla majątków uprzemysłowionych (tj. mających na swoim terenie zakłady przetwórstwa rolnego). Odszkodowanie dla właścicieli było równe cenie rynkowej ziemi, a nabywcy mogli się ubiegać o specjalne kredyty na spłatę należności 9 .

Reforma rolna była realizowana w różnym tempie (ogromne spowolnienie nastąpiło w okresie wielkiego kryzysu gospodarczego) do końca okresu międzywojennego. Jej konsekwencją było zmniejszenie powierzchni wielkich majątków ziemskich i rozparcelowanie przeszło 2,6 $\mathrm{mln} \mathrm{ha}{ }^{10}$. Nie rozwiązało to jednak problemu głodu ziemi na wsi ani nie powstrzymało postępującego rozdrobnienia agrarnego. Wprawdzie ziemia z parcelowanych majątków systematycznie zasilała istniejące już gospodarstwa chłopskie, jednak tradycyjne działy rodzinne powodowały, że obszar przeciętnego gospodarstwa wciąż malał. O ile w 1921 r. średnia powierzchnia gospodarstwa chłopskiego wynosiła 5,7 ha, to w 1938 r. powierzchnia ta zmalała do 5 ha. Pod koniec lat trzydziestych XX w. liczba gospodarstw małych, niesamowystarczalnych, wzrosła do $64,5 \%$ ogólnej liczby gospodarstw ${ }^{11}$.

Reforma rolna miała również wymiar pozaekonomiczny. Władze dążyły bowiem do wzmocnienia polskiego stanu posiadania na Kresach Wschodnich oraz w Wielkopolsce i na Pomorzu ${ }^{12}$. Na terenach byłego zaboru pruskiego liczba wielkich majątków, które w znacznej części znajdowały się w rękach niemieckich, do 1931 r. zmniejszyła się z 36,2\% do 19,2\% w Wielkopolsce, a na Pomorzu z 43,7\% do 22,3\%. Natomiast na Kresach Wschodnich realizowana była akcja osadnictwa wojskowego. Do 1922 r. osiedlono tam 6,6 tys. rodzin żołnierskich oraz ok. 16 tys. osadników cywilnych ${ }^{13}$. Ich sytuacja nie była łatwa. Trudności w zagospodarowaniu wy-

9 J. Kaliński, Z. Landau, op. cit., s. 64.

${ }^{10}$ Ibidem, s. 146.

${ }^{11}$ I. Kostrowicka, Z. Landau, J. Tomaszewski, Historia gospodarcza Polski XIX i XX wieku, Warszawa 1984, s. 363.

${ }^{12} \mathrm{Na}$ Śląsku wszystkie wielkie majątki znajdowały się w rękach niemieckich, jednak do 1937 r. ze względu na obowiązywanie konwencji genewskiej nie można było przeprowadzić żadnych zmian własnościowych na tym obszarze.

${ }^{13}$ Zasób ziemi przydzielanej żołnierzom stanowiły przejęte na rzecz Skarbu Państwa dobra rosyjskie, majątki rodziny panującej, majoraty, dobra poduchowne oraz opuszczone 
nikały z braku maszyn i narzędzi oraz inwentarza żywego, przede wszystkim jednak w nowym, obcym narodowościowo otoczeniu polscy osadnicy byli traktowani jak intruzi i często spotykali się z wrogością, a nawet bezpośrednimi atakami, co prowadziło do zaostrzenia konfliktów z miejscową ludnością.

\section{Warunki gospodarowania}

Poszczególne grupy mieszkańców wsi różniły się stylem życia oraz położeniem materialnym. Zazwyczaj poziom życia był najwyższy na obszarze dawnego zaboru pruskiego, a najniższy na Kresach Wschodnich. Sytuacja poszczególnych rodzin zależała jednak głównie od wielkości posiadanego gospodarstwa, jakości gleby, aktualnych cen na artykuły rolne oraz umiejętności gospodarowania. W latach dwudziestych stopniowo wyrównywały się różnice cywilizacyjne pomiędzy poszczególnymi częściami kraju14. Największy wzrost poziomu produkcji nastąpił w województwach wschodnich, natomiast w Wielkopolsce i na Pomorzu, gdzie dominowały gospodarstwa wysokotowarowe, widoczny był znaczny regres spowodowany odcięciem od rynku zbytu w Niemczech.

W pierwszych latach po wojnie powszechnie brakowało żywności, a w konsekwencji ustalano na nią dość wysokie ceny. Rolnicy musieli się jednak najpierw wywiązać z dostaw obowiązkowych (do 1921 r.), a na rynek mogli przeznaczyć jedynie nadwyżki. Również kolejne lata nie były korzystne dla rolników. W 1922 r. miał miejsce ogromny nieurodzaj. Spadały ceny na artykuły żywnościowe, a w okresie rosnącej inflacji rząd utrzymywał sztucznie niskie ceny, aby nie pogarszać warunków życia mieszkańców

majątki rolne. Na nich w pierwszej kolejności osiedlano byłych żołnierzy. Ochotnicy, inwalidzi wojenni oraz szczególnie zasłużeni otrzymywali ziemię bezpłatnie.

14 Jednym z najważniejszych wskaźników tych zmian była likwidacja analfabetyzmu ludności wiejskiej. Według danych z 1921 r. 38,1\% ludności wiejskiej nie potrafiło czytać i pisać. W wyniku podejmowanych przez państwo działań, a zwłaszcza obowiązkowej oświaty na poziomie szkoły podstawowej, odsetek ten spadł do 31\% w $1931 \mathrm{r}$. Najwięcej analfabetów było w województwach wschodnich, zob.: W. Mędrzecki, Chtopi, [w:] Spoteczeństwo polskie w XX wieku, red. J. Żarnowski, Warszawa 2003, s. 131. 
miast. Czynniki te wpłynęły negatywnie na kondycję ekonomiczną wsi, choć trzeba przyznać, że inflacja spowodowała również realne obniżenie wartości pieniądza i tym samym pobrane wcześniej kredyty oraz zaległości podatkowe były łatwiejsze do spłacenia.

Dzięki zmianom w produkcji oraz korzystnym warunkom atmosferycznym w połowie lat dwudziestych wyraźnie poprawiła się sytuacja na wsi. Jej przejawem były m.in. wzrost cen na artykuły rolne oraz zwiększone zakupy artykułów przemysłowych, zwłaszcza maszyn i urządzeń rolniczych. Część dochodów chłopi przeznaczali na powiększenie swoich gospodarstw, kupując ziemię poparcelacyjną. Modernizacja wsi nie miała jednak szerszego zasięgu. Zacofanie cywilizacyjne sprawiło również, że rolnicy szczególnie dotkliwie odczuli wielki kryzys gospodarczy. Gwałtownie spadły ceny na artykuły rolne. W 1935 r. za pszenicę chłopi otrzymywali jedynie 34\%, a za żyto 32\% cen obowiązujących w 1928 r. Podobny spadek dotyczył również innych płodów rolnych. Chłopi, aby uzyskać pieniądze niezbędne na opłacenie podatków, spłatę długów czy zakup artykułów przemysłowych, musieli sprzedać trzy razy więcej produktów. Możliwości zwiększenia produkcji były jednak ograniczone, gdyż brakowało pieniędzy na zakup nawozów sztucznych czy maszyn. W tej sytuacji pozostawało ograniczanie spożycia własnego i rodziny (zjawisko tzw. podaży głodowej). W ten sposób na rynku pojawiało się więcej żywności, co jednak prowadziło do dalszego spadku cen. Do tego dochodziła niekorzystna relacja między cenami żywności a cenami artykułów przemysłowych, tzw. nożyce cen. Chłopi rezygnowali zatem z zakupu większości towarów przemysłowych. Brak ubrań i obuwia był tak dotkliwy, że znaczna część dzieci nie uczęszczała do szkoły, nie mając się w co ubrać. Rezygnowano nawet z kupowania zapałek, powracając do stosowania hubki i krzesiwa (symbolem ówczesnej biedy na wsi było dzielnie zapałki na czworo). Największa pauperyzacja dotknęła posiadaczy małych i średnich gospodarstw, ale również spadły dochody właścicieli majątków ziemskich, czasami nawet o 40\%. Konsekwencją kryzysu był nie tylko regres w zakresie stosowania nowoczesnych metod produkcji oraz nawożenia, ale na niektórych obszarach wręcz powrót do gospodarki naturalnej. Znacznie wzrosło też przeludnienie agrarne, ponieważ z powodu bezrobocia w przemyśle coraz więcej osób usiłowało utrzymywać się z uprawy roli. Z ekonomicznego punktu widze- 
nia była to armia zbędnych ludzi (według różnych szacunków od 2,5 do 8 mln osób) $)^{15}$.

Rząd próbował wyprowadzić rolnictwo z przedłużającego się kryzysu, wprowadzając elementy interwencjonizmu, takie jak tworzenie rezerwy zbożowej na wypadek wojny czy inwestycje w dziedzinie przetwórstwa rolnego (budowa magazynów, elewatorów, mleczarni czy chłodni). Stosowano też odgórne mechanizmy mające na celu zahamowanie spadku cen na artykuły rolne oraz oferowano specjalne kredyty dla rolników. Wychodzenie z kryzysu przebiegało jednak powoli i dopiero jesienią 1935 r. widocznie poprawiła się sytuacja ludności wiejskiej. Ostatnie lata przed wojną upłynęły pod znakiem dobrej koniunktury. Zwiększyła się produkcja, rolnicy chętniej inwestowali w maszyny rolnicze i nawozy sztuczne. Ogólnie jednak poprawa sytuacji na wsi następowała znacznie wolniej niż w mieście.

\section{Eksploatacja wsi polskiej w czasie drugiej wojny światowej}

Już jesienią 1939 r. na obszarze ziem wcielonych do III Rzeszy Niemcy rozpoczęli wysiedlania Polaków do Generalnego Gubernatorstwa. Na opróżnionych gospodarstwach rolnych osiedlani byli Niemcy. Zdarzało się, że dokonywano komasacji kilku gospodarstw, aby utworzyć jedno większe gospodarstwo dla niemieckiego kolonisty. Do lutego 1942 r. władze niemieckie skonfiskowały blisko 900 tys. gospodarstw o powierzchni 9,2 mln ha. Od 1941 r. wysiedlenia zaczęto przeprowadzać również na obszarze Generalnego Gubernatorstwa. Najtragiczniejszy przebieg miały one na obszarze Zamojszczyzny ${ }^{16}$.

Część chłopów, których nie wysiedlono z ziem włączonych do III Rzeszy, przestała być właścicielami własnych gospodarstw i zostali poddani ścisłemu nadzorowi władz niemieckich, które decydowały o całości produkcji oraz wielkości konsumpcji własnej. Stała kontrola niemieckiego agronoma oraz obecność coraz liczniejszych niemieckich sąsiadów uniemożliwiały sprzedaż czy ukrycie części produkcji na własne potrzeby.

${ }^{15}$ J. Kaliński, Z. Landau, op. cit., s. 103.

${ }^{16}$ I. Kostrowicka, Z. Landau, J. Tomaszewski, op. cit., s. 421-422. 
Inna sytuacja była w Generalnym Gubernatorstwie, gdzie nie wprowadzono tak rygorystycznej kontroli nad całością produkcji rolnej. Rolnicy zostali wprawdzie obciążeni kontyngentami obejmującym praktycznie wszystkie płody rolne, ale mieli ograniczony wpływ na rodzaj upraw i hodowli. Znaczną część produktów (np. 40\% zbóż, 18\% ziemniaków, $73 \%$ buraków cukrowych) musieli sprzedawać po ustalonych urzędowo, bardzo niskich cenach, przy czym wysokość kontyngentów była stale zwiększana, co powodowało drastyczne obniżenie poziomu życia mieszkańców wsi (tab. 4).

Tabela 4. Kontyngenty zbożowe w Generalnej Guberni w latach 1940-1943

\begin{tabular}{|c|c|c|c|}
\hline Lata & $\begin{array}{c}\text { Kontyngenty } \\
\text { w tonach }\end{array}$ & Lata & $\begin{array}{c}\text { Kontyngenty } \\
\text { w tonach }\end{array}$ \\
\hline 1940 & 383000 & 1942 & 1200000 \\
\hline 1941 & 685000 & 1943 & 1500000 \\
\hline
\end{tabular}

Źródło: I. Kostrowicka, Z. Landau, J. Tomaszewski, Historia gospodarcza Polski XIX i XX wieku, Warszawa $1984 \ldots$, s. 425.

Za niewywiązanie się z obowiązku przymusowych dostaw oraz nielegalny handel groziły wysokie kary, z karą śmierci włącznie. Mimo to chłopi, szukając dodatkowych źródeł utrzymania, w miarę możliwości sprzedawali nielegalnie posiadane nadwyżki na czarnym rynku. Istnienie niewielkich nadwyżek żywności umożliwiało również przetrwanie oddziałom partyzanckim zdanym prawie całkowicie na pomoc ludności wiejskiej. Często ceną, jaką za jej udzielnie płacili mieszkańcy wsi, były brutalne represje, a nawet pacyfikacja całych miejscowości.

Eksploatacja gospodarcza polskiej wsi przez Niemców polegała również na wykorzystaniu siły roboczej. Ludność wiejska była masowo zatrudniana w przedsiębiorstwach działających na rzecz gospodarki niemieckiej na ziemiach okupowanych oraz wywożona na roboty przymusowe w głąb Rzeszy. Szacuje się, że spośród przeszło $3 \mathrm{mln}$ polskich robotników przymusowych ludność wiejska stanowiła około $75-80 \%{ }^{17}$.

${ }^{17}$ Ibidem, s. 400-401. 
Choć położenie materialne mieszkańców wsi nie pogarszało się tak szybko, jak sytuacja mieszkańców miast, to eksploatacja gospodarcza prowadzona przez okupanta doprowadziła do drastycznego obniżenia poziomu życia ludności wiejskiej. Szczególnie ciężka sytuacja miała miejsce w końcowym okresie wojny, gdy w wyniku działań wojennych zniszczeniu uległo średnio około 25\% budynków mieszkalnych i gospodarczych, prawie całkowicie wytrzebiono inwentarz żywy - konie, krowy, trzoda chlewna - zniszczono zasiewy, a zaminowane pola jeszcze długo po zakończeniu działań wojennych uniemożliwiały normalne prace polowe.

Na terenach okupowanych przez ZSRR już w 1939 r. wielka własność ziemska została przejęta przez państwo. Chcąc pozyskać poparcie chłopów, większość gruntów rozparcelowano, a z części utworzono sowchozy. Rozpoczęto walkę z bogatymi chłopami, tzw. kułakami, na których nałożono wysokie normy przymusowych dostaw artykułów rolnych. Przystąpiono też do kolektywizacji wsi (jej tempo było bardzo powolne i zostało przerwane w 1941 r. przez agresję III Rzeszy na ZSRR). Mieszkańcy wsi stanowili też większość obywateli polskich deportowanych w głąb ZSRR.

\section{Lata 1944-1956}

Ogromne straty, jakie poniosła wieś w wyniku drugiej wojny światowej, odbiły się negatywnie na kondycji całego społeczeństwa polskiego. Konieczność zaopatrzenia kraju w żywność sprawiła, że początkowo władze wspierały rozwój gospodarstw indywidualnych. Rolnicy mogli korzystać z kredytów na odbudowę gospodarstw, z pomocy w pozyskaniu materiału siewnego i zwierząt hodowlanych, rozpoczęto elektryfikację wsi. Zła sytuacja gospodarcza kraju sprawiała jednak, że pomoc dla wsi była zbyt mała w stosunku do potrzeb.

\section{Reforma rolna $w$ Polsce Ludowej}

W okresie międzywojennym nie udało się doprowadzić do rozwiązania kwestii agrarnej ani do likwidacji przeludnienia wsi. Sytuację tę postanowili wykorzystać komuniści, aby zdobyć poparcie ludności wiejskiej. 
Przeprowadzenie reformy rolnej stało się zatem jednym z najważniejszych haseł programowych Polskiej Partii Robotniczej. Z koniecznością przebudowy struktury agrarnej zgadzali się również przedstawiciele innych partii politycznych, w tym Polskiego Stronnictwo Ludowego, różniąc się jednak co do jej zasad. Rozwój sytuacji politycznej w Polsce sprawił, że ostateczny wpływ na sposób realizacji reformy mieli jedynie komuniści.

Zgodnie z zapowiedziami ogłoszonymi w Manifeście Polskiego Komitetu Wyzwolenia Narodowego z 22 lipca 1944 r., ziemia na upełnorolnienie i tworzenie nowych gospodarstw miała pochodzić ze zlikwidowanych majątków „obszarniczych” (o powierzchni ponad 50 ha, a w województwach poznańskim, gdańskim i śląskim - ponad $100 \mathrm{ha}$ ) oraz gospodarstw skonfiskowanych Niemcom i osobom uznanym za zdrajców narodu polskiego ${ }^{18}$. Szczegółowe zasady reformy zostały określone we wrześniu 1944 r. ${ }^{19}$ (dla ziem zachodnich i północnych dopiero we wrześniu $\left.1946 \mathrm{r}^{20}\right)$.

Przebieg reformy $\mathrm{w}$ poszczególnych częściach kraju różnił się dość istotnie. W najbardziej przeludnionych województwach południowych bardzo szybko wyczerpał się zapas ziemi uzyskanej z likwidacji wielkiej własności ziemskiej (w rzeszowskim czy lubelskim ziemi wystarczyło zaledwie dla ok. 20\% chętnych). Przyjęta norma 5 ha (dla nowotworzonych gospodarstw) okazała się zatem niemożliwa do utrzymania, toteż w praktyce średnia wielkość nowych gospodarstw na terenach wschodnich wynosiła ok. 2,8 ha ${ }^{21}$. Odwrotna sytuacja była na obszarach na zachód od Wisły. Pod zaborem pruskim mogły przetrwać tylko gospodarstwa silne ekonomicz-

${ }^{18}$ Manifest PKWN, [w:] Dokumenty programowe polskiego ruchu robotniczego 1878-1984 , red. N. Kołomejczyk, B. Syzdek, Warszawa 1986, s. 348. Zapowiedź wypłacenia zaopatrzenia dla byłych właścicieli nie została w Polsce zrealizowana, zob.: J. Skodlarski, op. cit., s. 371.

19 Dz.U. 1944 Nr 4, poz. 17. W dekrecie doprecyzowano m.in., że za uzyskaną ziemię chłopi będą płacić równowartość przeciętnych rocznych zbiorów, ale należność została rozłożona na 10-20 lat.

${ }^{20}$ Dekret z dnia 6 września 1946 r. o ustroju rolnym $i$ osadnictwie na Ziemiach Odzyskanych i obszarze bytego Wolnego Miasta Gdańska, Dz.U. 1946 Nr 49, poz. 279.

${ }^{21}$ I. Kostrowicka, Z. Landau, J. Tomaszewski, op. cit., s. 467; J. Kaliński, Historia gospodarcza Polski Ludowej, Białystok 2005, s. 10. 
nie, dlatego nie dzielono gospodarstw, ale przejmował je zwykle najstarszy ze spadkobierców ${ }^{22}$. Norma 5 ha była więc na tym obszarze nieatrakcyjna i nieuzasadniona ekonomicznie, tym bardziej że ziemi do podziału było sporo, ponieważ na parcelację przeznaczono również gospodarstwa poniemieckie. Dopiero podniesienie normy nowo tworzonych gospodarstw do 7 ha przejściowo zwiększyło zainteresowanie chłopów parcelacją. W praktyce jednak nowe gospodarstwa w Wielkopolsce były jeszcze większe i sięgały 10-12 ha. Dopiero w następstwie przeprowadzanych w późniejszym czasie kontroli zmniejszano je do ustalonych 7 ha. Chłopi reagowali na te przymusowe regulacje rezygnacją z przydzielonej im ziemi - zwroty dochodziły do $70-80 \%{ }^{23}$.

Jeszcze inaczej przedstawiała się sytuacja na ziemiach zachodnich i północnych, gdzie całość ziemi została przejęta przez państwo jako mienie poniemieckie. Na tym obszarze duże gospodarstwa o powierzchni powyżej 50 ha oraz wielkie majątki ziemskie powyżej 100 ha zajmowały łącznie $59,8 \%$ powierzchni użytków rolnych ${ }^{24}$. W planach nowych władz ziemie te zajmowały kluczowe miejsce. Zamierzano na nich osiedlić tę część ludności wiejskiej z ziem dawnych, dla której nie starczyło ziemi z parcelacji, oraz Polaków przyjeżdżających z terenu ZSRR i Zachodu. Znaczna nadwyżka ziemi oraz problemy z ich zasiedleniem pozwoliły zastosować wyższe niż $\mathrm{w}$ innych regionach normy przydziału ziemi (7-15 ha) ${ }^{25}$.

22 S. Jankowiak, Przemiany $w$ rolnictwie $w$ europejskich krajach socjalistycznych w okresie powojennym (do końca lat 1950.), [w:] „Zboże państwu”. Rolnictwo i wieś w plakacie propagandowym Europy Środkowo-Wschodniej z lat 1950. Katalog wystawy czasowej w Muzeum Narodowym Rolnictwa i Przemystu Rolno-Spożywczego w Szreniawie, Szreniawa 2010, s. 18.

${ }^{23}$ H. Słabek, op. cit., s. 124-126; S. Jankowiak, Przemiany $w$ rolnictwie, s. 19.

${ }^{24}$ J. Stanielewicz, Kolonizacja wewnętrzna na Pomorzu Zachodnim w dwudziestoleciu międzywojennym - próba ratowania czy rozktadu wielkiej wtasności?, [w:] Szlachta i ziemiaństwo polskie oraz niemieckie w Prusach i Niemczech $w$ XVIII-XX w., red. W. Stępiński, Szczecin 1996, s. 267; Łach S., Przeksztatcenia ustrojowo-gospodarcze w rolnictwie ziem zachodnich i pótnocnych w latach 1945-1949 (studium historyczne), Słupsk 1993, s. 61; idem, Rolnictwo na Pomorzu Zachodnim w latach 1945-1949, Słupsk 1985, s. 73-74.

${ }^{25} \mathrm{~K}$. Kersten, U podstaw ksztattowania się nowej struktury agrarnej ziem zachodnich (1945-1947), „Polska Ludowa. Materiały i Studia” 1962, t. 1, s. 41-42; S. Łach, Przeksztatcenia ustrojowo-gospodarcze..., s. 71. 
Choć rzeczywiście polska wieś potrzebowała zmian, to ostateczny bilans reformy nie był korzystny. Zmniejszyła się wprawdzie liczba gospodarstw najmniejszych, jednak utrzymało się znaczne rozdrobnienie wsi. Z krajobrazu wsi znikły natomiast całkowicie majątki ziemskie i duże, silne gospodarstwa indywidualne (tab. 5).

Tabela 5. Struktura agrarna gospodarstw chłopskich w latach 1938-1949 (w \%)

\begin{tabular}{|c|c|c|c|}
\hline Grupa obszarowa & $\mathbf{1 9 3 8} \mathbf{r}$ & $\mathbf{1 9 4 9} \mathbf{r .}$ & Zmiany \\
\hline Do 2 ha & 30,6 & 28,8 & -6 \\
\hline $2-5$ ha & 33,8 & 32,5 & -4 \\
\hline $5-10$ ha & 23,9 & 27,1 & +13 \\
\hline $10-20$ ha & 9,5 & 10,4 & +10 \\
\hline $20-50$ ha & 2,1 & 1,2 & -43 \\
\hline
\end{tabular}

Źródło: J. Kaliński, Z. Landau, Gospodarka Polski w XX wieku, Warszawa 2003..., s. 203.

Do 1949 r. rozparcelowano ok. $6 \mathrm{mln}$ ha ziemi, w tym ponad $3 \mathrm{mln}$ ha na ziemiach zachodnich i północnych. Rozparcelowano lub przejęto na własność państwa 13 tys. majątków ziemskich ${ }^{26}$. Na ziemiach dawnych utworzono 347 tys. nowych gospodarstw oraz powiększono 254 tys. starych, a przeciętny obszar nowych gospodarstw wynosił 5,4 ha. Na ziemiach nowych powstało 467 tys. gospodarstw o przeciętnej powierzchni 7,9 ha ${ }^{27}$.

Małe gospodarstwa były słabe ekonomicznie, niezdolne do intensyfikacji produkcji oraz bardzo podatne na presję podatkową, a tym samym bardziej zależne od polityki państwa ${ }^{28}$. W ten sposób został przygotowany grunt do późniejszej próby kolektywizacji ${ }^{29}$. Równocześnie z realizacją reformy rolnej część majątków ziemskich wyłączono z parcelacji w celu budowy sektora państwowego w rolnictwie. Łącznie przeszło $3 \mathrm{mln}$ ha pozostało

${ }^{26}$ M. Batowski, Gospodarka socjalistyczna w Polsce. Geneza - rozwój - upadek, Warszawa 2009, s. 149.

27 J. Kaliński, Z. Landau, op. cit., s. 203.

${ }_{28}$ M. Mieszczankowski, op. cit., s. 329; J. Kaliński, Z. Landau, op. cit., s. 203.

${ }^{29}$ J. Kaliński, Z. Landau, op. cit., s. 204; S. Jankowiak, Przemiany w rolnictwie..., s. 26. 
w posiadaniu państwa, z tego najwięcej (ok. 2/3 tego obszaru) znajdowało się na ziemiach zachodnich i północnych.

Reforma miała zapewnić komunistom masowe poparcie wsi, dlatego ogromnym zaskoczeniem był dla nich opór ze strony części chłopów, którzy nie chcieli oni brać przydzielanej im „pańskiej ziemi” z obawy przed nietrwałością nowego ustroju. Zaufanie chłopów zostało zresztą nadwerężone już wkrótce, kiedy w 1948 r. władze przystąpiły do tzw. regulacji nadziałów, a następnie do kolektywizacji. Reforma wpłynęła również na zmianę struktury polskiego społeczeństwa - przestało istnieć ziemiaństwo jako warstwa społeczna oraz radykalne zmniejszyła się liczba zamożnych chłopów.

\section{Kolektywizacja}

Koniec lat czterdziestych XX w. to początek wielkich zmian w rolnictwie i próba całkowitej przebudowy polskiej wsi na wzór radziecki. Miały się one dokonać w drodze kolektywizacji, ograniczenia liczby gospodarstw indywidualnych, zwłaszcza tzw. kułackich, oraz rozbudowy sektora państwowego. U podłoża tych zmian leżały głównie przesłanki ideologiczne, a władze komunistyczne nie liczyły się ani z uwarunkowaniami społecznymi, ani z konsekwencjami ekonomicznymi.

Początkowo komuniści odwlekali decyzję o uspółdzielczeniu wsi, a nawet zaprzeczali istnieniu takich planów ${ }^{30}$. Zdawali sobie bowiem sprawę, że na wsi nie ma atmosfery sprzyjającej wprowadzeniu takiego rozwiązania $^{31}$. Spółdzielnie produkcyjne szczególnie źle kojarzyły się tym, którzy mieli okazję poznać funkcjonowanie kołchozów w ZSRR. Jednak we wrześniu 1948 r., pod naciskiem Stalina, Polska Zjednoczona Partia Robotnicza zadecydowała o natychmiastowym przystąpieniu do kolekty-

${ }^{30}$ H. Słabek, op. cit., s. 127; J. Kaliński, Z. Landau, op. cit., s. 202.

${ }^{31}$ Do jej realizacji przystąpiono dopiero po wyeliminowaniu ze sceny politycznej PSL. Podobna sytuacja miała miejsce w Czechosłowacji i na Węgrzech, gdzie do kolektywizacji przystąpiono również po klęsce partii agrarnych, zob.: W. Mędrzecki, Chłopi..., s. 148 . 
wizacji ${ }^{32}$. Za jej realizację odpowiadały komitety wojewódzkie i powiatowe PZPR. Zakładaniu spółdzielni produkcyjnych towarzyszyła szeroka i agresywna akcja propagandowa prowadzona w prasie i radiu. Do propagowania kolektywizacji zostały zobowiązane wszystkie instytucje kulturalno-oświatowe, szkoły i organizacje społeczne działające w środowiskach wiejskich. W miastach organizowano brygady robotnicze i młodzieżowe, które wyjeżdżały na wieś i agitowały na rzecz tworzenia spółdzielni ${ }^{33}$.

Mimo ogromnej kampanii propagandowej w 1949 r., pierwszym roku kolektywizacji, powstało tylko 243 spółdzielni skupiających zaledwie $0,1 \%$ wszystkich gospodarstw. W ocenie władz wyniki te były zbyt niskie, dlatego sięgnięto po metody administracyjne, represje polityczne, przymus fizyczny i sankcje ekonomiczne, za pomocą których zmuszano chłopów do wstępowania do spółdzielni. Wobec opornych stosowano różnorodne represje: zwiększano obciążenia podatkowe, rekwirowano zboże i żywiec, karano mandatami, aresztami lub zsyłano do obozów pracy. Wieś została obciążona także dodatkowymi podatkami, np. obowiązkową składką na Społeczny Fundusz Rozwoju Rolnictwa ${ }^{34}$. Szczególnie ostro byli zwalczani bogatsi chłopi, czyli tzw. kułacy, ogłoszeni przez partię wrogami państwa ${ }^{35}$. Najbardziej znane przypadki terroru w trakcie tworzenia spółdzielni miały miejsce na terenie powiatu gryfickiego w 1951 r., jednak podobne metody były stosowane w całym kraju ${ }^{36}$.

Chłopi próbowali się bronić, występując z podaniami o zmniejszenie obszaru gospodarstwa. Chcieli w ten sposób zmniejszyć wymiar podatku

${ }^{32}$ H. Minc, Bieżące zadania Partii w zakresie polityki gospodarczej i spotecznej na wsi. Referat wygtoszony na Plenym KC PPR w dniu 3 IX 1948 r., „Nowe Drogi” 1948, nr 11, s. $156-183$

${ }^{33}$ K. Kozłowski, Między racją stanu a stalinizmem. Pierwsze dziesięć lat wtadzy politycznej na Pomorzu Zachodnim 1945-1955, Warszawa-Szczecin 2000, s. 194-196.

${ }^{34}$ R. Winiewska, Obciążenia podatkowe gospodarstw chtopskich $w$ Polsce $w$ latach 1945-1955, Warszawa 1961, s. 44-49.

${ }_{35}$ M. Nadolski, Komuniści wobec chtopów w Polsce 1941-1956. Mity i rzeczywistość, Warszawa 1993, s. 203; S. Jankowiak, Wielkopolski kutak wrogiem państwa socjalistycznego, „Biuletyn Instytutu Pamięci Narodowej” 2002, nr 1, s. 30.

36 Por. szerzej: K. Kozłowski, Materiaty archiwalne do „wydarzeń gryfickich” z 1951 r., Szczecin 1992; M. Machałek, Przemiany wsi zachodniopomorskiej, Szczecin 2012, s. 239-273. 
lub zmienić polityczną klasyfikację (przestawali być kułakami). Bardziej radykalną postawą było zrzekanie się lub porzucanie gospodarstw, zwłaszcza na ziemiach zachodnich i północnych ${ }^{37}$.

Tempo powstawania spółdzielni było zróżnicowane. Najtrudniej było zmusić chłopów do zakładania spółdzielni tam, gdzie ziemia należała do nich od pokoleń. W starych wsiach w województwach kieleckim, krakowskim, warszawskim, łódzkim, lubelskim proces tworzenia spółdzielni przebiegał zatem bardzo wolno. Natomiast na ziemiach zachodnich i północnych, gdzie dominowały gospodarstwa osadnicze i poparcelacyjne, przywiązanie chłopa do ziemi było o wiele mniejsze, a liczba spółdzielni zdecydowanie wyższa ${ }^{38}$. Do końca 1955 r. utworzono blisko 10 tys. spółdzielni, które użytkowały ok. 1,9 mln ha gruntów rolnych, czyli ok. 9\% powierzchni użytków rolnych w kraju ${ }^{39}$. Różnice w stopniu uspółdzielczenia poszczególnych województw ilustruje tabela 6 .

Tabela 6. Stopień uspółdzielczenia chłopskich użytków rolnych według czerwcowych spisów rolnych (1953-1956) w odsetkach

\begin{tabular}{|c|c|c|c|c|}
\hline \multirow{2}{*}{ Województwo } & \multicolumn{5}{|c|}{ Rok } \\
\cline { 2 - 5 } & $\mathbf{1 9 5 3}$ & $\mathbf{1 9 5 4}$ & $\mathbf{1 9 5 5}$ & $\mathbf{1 9 5 6}$ \\
\hline cała Polska & 7,7 & 9,4 & 10,6 & 11,2 \\
\hline warszawskie & 1,4 & 1,7 & 1,9 & 2,1 \\
\hline bydgoskie & 8,7 & 13,5 & 16,5 & 18,3 \\
\hline poznańskie & 9,7 & 14,4 & 16,7 & 18,2 \\
\hline tódzkie & 1,7 & 2,0 & 2,7 & 2,6 \\
\hline kieleckie & 0,7 & 0,8 & 1,0 & 1,0 \\
\hline lubelskie & 2,3 & 3,4 & 3,3 & 3,1 \\
\hline białostockie & 3,0 & 3,3 & 3,6 & 3,6 \\
\hline
\end{tabular}

${ }^{37}$ M. Machałek, Przemiany wsi..., s. 259-263.

38 J. Kaliński, Z. Landau, op. cit., s. 249.

39 D. Jarosz, Polityka wtadz komunistycznych $w$ Polsce $w$ latach 1948-1956 a chtopi, Warszawa 1998, s. 22; J. Skodlarski, op. cit., s. 403; J. Kaliński, Z. Landau, op. cit., s. 249. 
Cd. tab. 6

\begin{tabular}{|c|r|r|r|c|}
\hline \multirow{2}{*}{ Województwo } & \multicolumn{4}{|c|}{ Rok } \\
\cline { 2 - 5 } & $\mathbf{1 9 5 3}$ & $\mathbf{1 9 5 4}$ & $\mathbf{1 9 5 5}$ & $\mathbf{1 9 5 6}$ \\
\hline olsztyńskie & 8,2 & 9,3 & 10,2 & 10,8 \\
\hline gdańskie & 15,5 & 17,0 & 18,8 & 19,6 \\
\hline koszalińskie & 14,5 & 15,3 & 18,4 & 21,5 \\
\hline szczecińskie & 36,6 & 40,8 & 44,8 & 45,5 \\
\hline wroctawskie & 28,8 & 35,3 & 39,8 & 41,2 \\
\hline opolskie & 21,3 & 24,0 & 25,9 & 26,6 \\
\hline katowickie & 2,0 & 2,4 & 2,4 & 2,6 \\
\hline krakowskie & 1,2 & 1,4 & 1,6 & 1,7 \\
\hline rzeszowskie & 4,2 & 5,1 & 5,3 & 5,6 \\
\hline
\end{tabular}

Źródło: D. Jarosz, Polityka wtadz komunistycznych w Polsce w latach 1948-1956 a chtopi, Warszawa $1998 \ldots$... s. 109.

Przymus wstępowania do kolektywów oraz brak tradycji wspólnego gospodarowania i poczucia własności powodowały, że większość spółdzielców nie była zainteresowania wynikami pracy. Bardziej dbali o swoje działki przyzagrodowe niż o majątek spółdzielni. Nie dziwi zatem, że wydajność spółdzielni była znacznie niższa niż wydajność gospodarstw indywidualnych, które pomimo obciążeń i ograniczeń osiągały w przeliczeniu na 1 ha użytków rolnych wyniki wyższe o $14 \%{ }^{40}$.

Następstwem forsownej kolektywizacji i drenażu ekonomicznego wsi było załamanie produkcji rolnej w 1951 r. Aż do 1955 r. nie udało się powrócić do poprzedniego stanu. Chłopi, obawiając się utraty swoich gospodarstw, rzadko decydowali się na inwestycje. Możliwości modernizacji były zresztą niewielkie ze względu na obciążenia podatkowe. Władze wprowadziły też liczne ograniczenia w nabywaniu nawozów czy maszyn rolniczych oraz sztucznie utrzymywały niski poziom cen urzędowych na produkty rol-

${ }^{40}$ J. Kaliński, Z. Landau, op. cit., s. 249-250. 
ne. Postępowała zatem pauperyzacja chłopów, a zmonopolizowanie przez państwo cen skupu i sprzedaży produktów rolnych oraz ustalanie limitów kontraktacji prowadziło do całkowitego uzależnienia ich od władz administracyjnych i gospodarczych ${ }^{41}$. Pogorszyła się też struktura obszarowa gospodarstw - nastąpił spadek liczby gospodarstw o powierzchni powyżej 5 $\mathrm{ha}^{42}$. W tej sytuacji coraz więcej właścicieli małych gospodarstw było zmuszonych do poszukiwania dodatkowej pracy poza rolnictwem, zwiększając liczebność kategorii chłoporobotników ${ }^{43}$.

\section{Budowa sektora państwowego $w$ rolnictwie}

Choć podstawą ustroju rolnego w powojennej Polsce, zgodnie z deklaracjami władz, miały być gospodarstwa indywidualne, to już w trakcie realizacji reformy rolnej przystąpiono do tworzenia sektora państwowego, przeznaczając na ten cel 10\% ogólnego areału użytków rolnych. W 1946 r. zostało utworzone przedsiębiorstwo Państwowe Nieruchomości Ziemskie (PZN), które miało zagospodarować opuszczone i zdewastowane majątki na obszarze ziem zachodnich i północnych ${ }^{44}$. Wkrótce rozszerzono działalność PNZ również na ziemie dawne, choć państwo przejęło tam zdecydowanie mniej ziemi ${ }^{45}$. W 1946 r. z ogólnego obszaru 1,6 mln ha należących do państwa, na ziemiach nowych znajdowało się aż 1,3 $\mathrm{mln} \mathrm{ha}^{46}$. W kolejnych miesiącach stan posiadania PNZ zmieniał się dynamicznie - przejmowano kolejne majątki, a inne oddawano na parcelację.

$\mathrm{Na}$ początku 1949 r. wszystkie gospodarstwa państwowe (nieruchomości ziemskie, hodowlę roślin i chów koni) połączono, tworząc Państwowe

${ }^{41}$ W. Mędrzecki, Chtopi..., s. 153.

42 J. Kaliński, Z. Landau, op. cit., s. 252.

${ }^{43}$ W. Mędrzecki, Chtopi..., s. 159.

${ }^{44}$ P. Dziurzyński, Osadnictwo rolne na Ziemiach Odzyskanych, Warszawa 1983, s. 128; por.: H. Duda, Państwowe Nieruchomości Ziemskie w Opolu (1946-1949). Zarys monograficzny, Opole 2006.

${ }^{45}$ W. Rogala, Dziatalność Panstwowych Nieruchomości Ziemskich (1946-1949), „Rocznik Muzeum Rolnictwa w Szreniawie” 1972, nr 5, s. 31.

${ }^{46}$ W. Maringe, E. Englicht, Panstwowe Gospodarstwa Rolne (zarys rozwoju w kolejnych okresach), „Zagadnienia Ekonomiki Rolnej” 1959, nr 4 (34), s. 38. 
Gospodarstwa Rolne (PGR). Weszły one na trwałe do krajobrazu polskiej wsi i stały się jednym z symboli socjalistycznych przemian w rolnictwie. W założeniu miały być wzorcowymi gospodarstwami gwarantującymi dostawy żywności dla rosnącej w wyniku industrializacji ludności miast. W rzeczywistości, mimo stosowanych preferencji, efektywność PGR była nie tylko znacznie niższa od wyników uzyskiwanych przez gospodarstwa indywidualne, ale wiele $\mathrm{z}$ nich przynosiło permanentne straty. W przeliczeniu na gotówkę produkcja globalna z 1 ha użytków rolnych w 1955 r. wynosiła w gospodarstwach chłopskich 621 zł, w spółdzielniach produkcyjnych 517 zł, a w PGR zaledwie 394 zł. Jedynie wysokość produkcji zbożowej, dzięki mechanizacji, była zbliżona do gospodarstw chłopskich ${ }^{47}$.

Przyczyną tak niskich wyników były przede wszystkim błędy w zarządzaniu, odgórnie narzucane plany gospodarcze nieuwzględniające lokalnych warunków, ale też znaczne obciążenia świadczeniami socjalnymi na rzecz pracowników oraz obowiązek zagospodarowania odłogów ${ }^{48}$. Do tego dochodziła ogromna niegospodarność, marnotrawstwo, kradzieże oraz brak dyscypliny pracy i zatrudnionych w nich pracowników, co w połączeniu z ciężkimi warunkami, słabym wykształceniem zatrudnionych tam robotników rolnych oraz relatywnie niskimi wynagrodzeniami za pracę sprawiało, że gospodarstwa państwowe kontrastowały z kreowanym przez oficjalną propagandę wizerunkiem PGR jako wzorcowego gospodarstwa socjalistycznego.

Do 1955 r. w skali kraju powstało przeszło 6 tys. gospodarstw państwowych obejmujących $12 \%$ użytków rolnych. Dwie trzecie PGR znajdowało się na ziemiach zachodnich i północnych, 1/4 w poznańskim, bydgoskim i gdańskim, a w pozostałych województwach - zaledwie $1 / 1049$. Obszar ziemi znajdującej się we władaniu państwa stale rósł, osiągając w 1990 r. najwyższy pułap (najwięcej, bo przeszło 50\% gruntów użytkowały PGR w województwach koszalińskim i szczecińskim).

47 J. Skodlarski, op. cit., s. 404.

48 W. Dzun, Państwowe gospodarstwa rolne $w$ procesie przemian systemowych $w$ Polsce, Warszawa 2005, s. 20.

${ }^{49}$ I. Bukraba-Rylska, op. cit., s. 348. 


\section{Lata 1956-1989}

Rok 1956 przyniósł istotne zmiany również dla wsi. Najbardziej spektakularny był rozpad większości spółdzielni produkcyjnych. Z blisko 10 tys. spółdzielni przetrwało zaledwie 1,5 tys. Przyczyną tak szybkiego rozpadu kolektywów były obawy chłopów, że atmosfera polityczna pozwalająca na te działania wkrótce się zmieni ${ }^{50}$. Charakterystyczne, że tempo dekolektywizacji było największe na ziemiach nowych, czyli tam, gdzie utworzono ich najwięcej ${ }^{51}$. W euforii towarzyszącej przemianom październikowym większość mieszkańców wsi odczytała wypowiedzi Władysława Gomułki oraz uchwały VIII Plenum Komitetu Centralnego PZPR jako odejście od kolektywizacji wsi. W rzeczywistości władze partyjne i państwowe nie zrezygnowały z niej, a jedynie odłożyły w czasie i wybrały drogę pośrednią, forsując tworzenie kółek rolniczych, które miały przygotować chłopów do zbiorowych form gospodarowania.

Po październiku 1956 r. zmianie uległa też polityka państwa wobec rolników indywidualnych. Ograniczone zostały dostawy obowiązkowe płodów rolnych, podniesiono ceny skupu, a także nieco złagodzono politykę podatkową i umożliwiono chłopom korzystanie z kredytów bankowych. Ustępstwa te zaowocowały nie tylko zmianą nastrojów na wsi, ale również natychmiastowym wzrostem produkcji rolnej. W 1957 r. odnotowano najwyższy po wojnie wskaźnik produkcji rolnej, nadal jednak problemem było niedostateczne zaopatrzenie rynku w produkty żywnościowe.

Lata sześćdziesiąte upłynęły w rolnictwie pod znakiem stagnacji, a w latach 1962 i 1964 z powodu nieurodzaju poziom produkcji spadł do stanu przedwojennego. Jednocześnie w związku z urbanizacją i industrializacją gwałtownie wzrastało zapotrzebowanie na żywność. Szczególne niezadowolenie społeczne wywoływały braki w zaopatrzeniu w mięso i jego przetwory. Problemy próbowano rozwiązać, zwiększając import zbóż, głównie

${ }^{50}$ D. Jarosz, op. cit., s. 152.

${ }^{51} \mathrm{~W}$ województwie szczecińskim rozwiązało się aż 98\% kolektywów, we wrocławskim - 97,5\%, w zielonogórskim - 96,2\%, a w opolskim - 92,4\%, zob.: ibidem, s. 151; R. Skobelski, Specyfika kolektywizacji rolnictwa na ziemiach zachodnich i pótnocnych Polski w latach 1948-1956, [w:] Dzieje i przysztość polskiego ruchu ludowego, t. 2: Polska Ludowa (1944/45-1989), red. W. Paruch, S. J. Pastuszka, R. Turkowski, Warszawa 2002, s. 320. 
na potrzeby hodowli. Czynnikami hamującymi wzrost produkcji w gospodarstwach indywidualnych były, oprócz wysokich podatków, zbyt niskie, regulowane urzędowo ceny na artykuły żywnościowe oraz ekstensywne metody produkcji. Na niską efektywność gospodarki miały też wpływ takie czynniki, jak mała powierzchnia gospodarstw, ograniczone możliwości zakupu maszyn czy nawozów sztucznych oraz coraz bardziej widoczne procesy starzenia się wsi. Trudne warunki gospodarowania i brak perspektyw poprawy sytuacji materialnej powodowały, że coraz mniej młodych ludzi decydowało się na pozostanie na wsi ${ }^{52}$.

Bardziej odczuwalne zmiany polityki państwa wobec rolników indywidualnych nastąpiły dopiero w latach siedemdziesiątych i wynikały ze stale pogarszającej się sytuacji aprowizacyjnej kraju. Władze zdawały sobie wówczas sprawę, że PGR-y nie będą w stanie zapewnić społeczeństwu wystarczającej ilości żywności. W 1972 r. zostały zniesione dostawy obowiązkowe, a rolnicy mogli korzystać z kredytów inwestycyjnych. Priorytetem w zaopatrzeniu nadal były gospodarstwa państwowe, ale rolnicy indywidualni w zamian za umowy kontraktacyjne mogli uzyskać przydziały deficytowych maszyn, narzędzi czy nawozów ${ }^{53}$. Umożliwiono również powiększanie gospodarstw do 8 ha, a nawet 20 ha, jednocześnie zabraniając podziałów na gospodarstwa mniejsze niż 8 ha użytków rolnych, co miało zapobiec nadmiernemu rozdrobnieniu. Po raz pierwszy rolnicy i ich rodziny zostali objęci bezpłatną opieką zdrowotną. Zostało im również przyznane prawo do świadczeń emerytalnych, choć początkowo wyłącznie w zamian za zdanie gospodarstwa rolnego na skarb państwa. Zmiany te zostały pozytywnie odebrane przez część rolników, zwłaszcza młodych i posiadających wykształcenie rolnicze, którzy przestawili się na intensyfikację i specjalizację produkcji. Większość jednak, zwłaszcza w województwach wschodnich, pozostała przy tradycyjnych metodach gospodarowania ${ }^{54}$.

Niezależnie od ustępstw na rzecz rolników, władze nadal intensywnie wspierały sektor państwowy. Z myślą o gospodarstwach państwowych powstawały fabryki nawozów sztucznych oraz maszyn rolniczych (np. Ursus).

\footnotetext{
52 J. Kaliński, Z. Landau, op. cit., s. 265-266, J. Skodlarski, op. cit., s. 441.

53 W. Mędrzecki, Chtopi..., s. 156.

${ }^{54}$ Ibidem, s. 160.
} 
Systematycznie zwiększał się areał PGR-ów, które przejmowały m.in. oddawane za rentę gospodarstwa indywidualne. W ten sposób w użytkowanie PGR-ów tylko w pierwszej połowie lat siedemdziesiątych przeszło $10 \%$ gruntów chłopskich. Poza okresem forsownej kolektywizacji był to największy ubytek chłopskiego stanu posiadania. Konsekwencją wzrostu areału użytków rolnych był znaczny wzrost zatrudnienia - pracownicy PGR-ów wraz z rodzinami stanowili grupę liczącą blisko $1 \mathrm{mln}$ osób (tab. 7). W $1970 \mathrm{r}$. PGR-y gospodarowały już na 16\% gruntów ornych, jednak ich produkcja - pomimo dużych nakładów - wynosiła jedynie 14\% produkcji globalnej55.

Tabela 7. Zmiany powierzchni i zatrudnienia w Państwowych Gospodarstwach Rolnych

\begin{tabular}{|c|c|c|c|}
\hline Lata & $\begin{array}{c}\text { Powierzchnia } \\
\text { (tys. ha) }\end{array}$ & $\begin{array}{c}\text { Zatrudnienie } \\
\text { (tys.) }\end{array}$ & $\begin{array}{c}\text { Liczba } \\
\text { pracowników } \\
\text { (osoby na 100 ha) }\end{array}$ \\
\hline 1950 & 2212 & 276,3 & 15,1 \\
\hline 1960 & 2922 & 339,3 & 14,0 \\
\hline 1970 & 3393 & 391,4 & 13,6 \\
\hline 1980 & 4216 & 490,3 & 13,3 \\
\hline 1990 & 3935 & 395,0 & 12,1 \\
\hline
\end{tabular}

Źródło: I. Bukraba-Rylska, Socjologia wsi polskiej, Warszawa 2008, s. 347.

Po 1980 r. poprawiła się nieco sytuacja prawna gospodarstw indywidualnych (zniesiono wówczas m.in. utrudnienia w dziedziczeniu ziemi) ${ }^{56}$, jednak sytuacja ekonomiczna rolnictwa była zła. Niska mechanizacja produkcji, zbyt mała produkcja środków ochrony roślin i nawozów powodowały, że wysokość produkcji rolnej była znacznie niższa niż na Zachodzie. Narastały i tak ogromne problemy z zaopatrzeniem w żywność. Sytuacja pogorszyła się znacznie po wprowadzeniu stanu wojennego, gdy w wyniku restrykcji państw zachodnich został wstrzymany import m.in. pasz, co doprowadziło do załamania hodowli.

55 J. Kaliński, Z. Landau, op. cit., s. 287.

56 W. Mędrzecki, Chtopi..., s. 152. 
Przez cały okres po drugiej wojnie światowej systematycznie zmieniała się struktura zawodowa mieszkańców wsi. Coraz mniej osób utrzymywało się z pracy na roli. Zmniejszał się też dystans cywilizacyjny między wsią a miastem. W latach siedemdziesiątych wyposażenie gospodarstwa domowego na wsi (chłopskiego lub pracownika PGR) nie odbiegało znacząco od wyposażenia gospodarstwa domowego w mieście. Następował proces zacierania różnic kulturowych między wsią a miastem. Sprzyjały temu: powszechna oświata, popularyzacja czytelnictwa, prasa, a następnie radio i telewizja. Głównie pod ich wpływem następował proces porzucenia kultury ludowej na rzecz miejskiego stylu życia realizowanego w warunkach wiejskich ${ }^{57}$. Szybciej zmiany te zachodziły w środowisku robotników rolnych w PGR-ach, mających normowany czas pracy, niż wśród rolników indywidualnych, którzy zazwyczaj pracowali od świtu do zmierzchu. Widać to chociażby na przykładzie udziału w życiu kulturalnym i towarzyskim koncentrującym się wokół świetlic wiejskich, a od lat sześćdziesiątych - klubokawiarni. Ich gośćmi częściej bywali mieszkańcy osiedli pegeerowskich niż rolnicy. Tradycyjna kultura ludowa, zwyczaje i tradycje, choć oficjalnie uznawane za wartościowe, coraz częściej były kultywowane jedynie przy okazji świąt i uroczystości niż z wewnętrznej potrzeby mieszkańców wsi.

Rok 1989 przyniósł zasadnicze zmiany również w sytuacji polskiej wsi, wprowadzając mechanizmy rynkowe. Nie dla wszystkich okazały się one korzystne. Znaczna część właścicieli małych gospodarstw nie wytrzymała konkurencji. Rozpoczął się proces koncentracji ziemi ${ }^{58}$. Z krajobrazu wsi zniknęły też zlikwidowane w 1991 r. PGR-y ${ }^{59}$, pozostawiając nierozwiązany do dziś problem bezrobocia na obszarach, gdzie było ich najwięcej (zachodniopomorskie, warmińsko-mazurskie, lubuskie) ${ }^{60}$. W wyniku me-

57 Ibidem, s. 161.

58 I. Bukraba-Rylska, op. cit., s. 205.

59 Ustawa z dnia 19 października 1991 r. o gospodarowaniu nieruchomościami rolnymi Skarbu Państwa, Dz.U. 1991 Nr 107, poz. 464.

${ }^{60}$ M. Machałek, Wokót genezy spotecznych konsekwencji obecności państwowych gospodarstw rolnych na wsi zachodniopomorskiej, [w:] Od polonizacji do europeizacji Pomorza 
chanizacji gwałtownie zmalało zatrudnienie w rolnictwie i przekształceniu uległa struktura zawodowa wsi. Przyspieszeniu uległy również przemiany cywilizacyjne, ale jednocześnie pogłębiły się różnice w poziomie życia poszczególnych grup mieszkańców wsi.

\section{Changes in the polish countryside in the years 1918-1989}

(SUMmarY)

In the prewar period problems of Polish countryside were fragmentation and overpopulation. In spite of the land reform the farms were mainly smaller than 5 hectares and the peasants practiced the extensive farming. Only the part of bigger farms, mainly in Western and Middle Poland, was modern. The Great Depression led to 66\% agricultural goods prices drop and it lasted until 1945.

The Polish countryside during the World War II suffered enormous material and demographic loss. After the end of the war the radical land reform was introduced, which deepened agricultural fragmentation. Some part of the land remained in government's possession and were transformed into State Agricultural Farm (Państwowe Gospodarstwo Rolne, PGR). The area of this farms were extended systematically, particularly in the western and northern Poland's areas. In 1948 the government started to collectivize the countryside. The famers were forced with restrain and repression to join the cooperative farms. After 1956 the most of the cooperative farms fell apart and the policy has been lightened, e.g. reducing compulsory deliveries. The deepening depression of the 70's led to the prices drop and the collapse in the agricultural industry, which caused the breakdown of food supply. The bad condition of agriculture lasted until the last days of People's Republic of Poland.

\section{Małgorzata Machałek Uniwersyteckie Centrum Edukacji, Uniwersytet Szczeciński m.machalek@op.pl}

Zachodniego, red. M. Machałek, J. Macholak, E. Włodarczyk, Warszawa-Szczecin 2012, s. 289-302. Szerzej na ten temat: E. Tarkowska, K. Korzeniewska, Mtodzież z bytych PGR-ów. Raport z badań, Warszawa 2002, s. 5. 